\title{
'Knowing-with' in the era of Anthropocene
}

At the beginning of June 2018, while preparations were being made to welcome the delegates of the TEFI1o conference to Pyhä-Luosto national park, the Guardian (Carrington, 2018) published breaking news: according to a recent assessment, the human race - just $0.01 \%$ of all life - was eradicating all other living things (Bar-On, Phillips, \& Milo, 2018). One and a half years have passed since the conference and that staggering news, and discussions related to humans' devastating power are all around us. At the same time, the research endeavours conducted since the conference have revealed not only concerns, but also important glimpses of hope and optimism.

The chosen themes of the TEFI10 conference did not settle with the idea of merely minimising tourism's impacts. Instead, our new, up-to-date task as tourism educators and researchers is to develop knowledge that is based on more sensitive entanglements between the Earth's systems and humanity. In line with this task, we now call attention to how we can seek to knowwith objects, things, humans, landscapes, animals, elements, and theories, both through our research activities and in our pedagogical efforts. Our hope is to slow down to reflect on and discuss the roles of tourism research and education in the current era in which human actions are causing irreversible changes to the Earth's systems - in the era of the Anthropocene (Gren \& Huijbens, 2014). While recognising and fearing for the exponential environmental impacts embedded in the tourism industry, the idea of knowing-with encourages us to explore the possibilities of togetherness enabled by tourism mobilities. Tourism permits, on one hand, encounters with human and more-than-human others, whose ways of knowing can be radically different from us. On the other hand, tourism settings also make it possible to recognise similarities and to question stereotypical images about 'the other'. Hence, instead of focusing on tourism as the 'world's largest industry', or as one of the biggest villains in the Anthropocene, the idea of knowing-with can help us to draw attention to encounters, togetherness, and epistemological entanglements that become possible within the tourism framework.

Knowing-with is about togetherness, about being in relations with multiple others. While this can be used to refer to knowledge collectives formed by tourism scholars, the fruitfulness of the notion of knowing-with lies in the way in which it helps us to recognise our entanglements with a wider range of creatures (Ren, Jóhannesson, \& van der Duim, 2018). The era of the Anthropocene has challenged us to acknowledge both the limitations of human-centred ways of 
knowing and the illusion of recognising only humans as 'masters of knowledge' (Caton, 2018; Ulmer, 2017). The recent new-materialist approach especially underlines the importance of recognising and respecting how we are living, entangling, and knowing with more-than-human actors (Alaimo \& Hekman, 2008; Barad, 2003; Braidotti, 2013; Haraway, 2015). The new-materialist turn has drawn attention to the previously marginalised or objectified voices that have essential knowledge about the ongoing environmental catastrophe. In other words, we are challenged to radically enlarge our idea of who and what has knowledge - who and what we can know-with. This means also questioning the linear idea of academic research in which raw material is being collected 'over there' in field settings and then developed into knowledge 'in here' by our desks.

While advocating for creative forms of knowing-with, it is important to keep in mind how the desire to recognise otherness and other ways of knowing, and to give voice to those at the margin, always comes with challenges. For instance, as typical in the era of the Anthropocene, human intentions to 'listen' to other creatures tend to be driven by instrumentalism, in which knowledge is extracted from others for one's own purposes (Caton, 2018, pp. 196-197). Another challenge is the risk of paternalising or romanticising those human and more-than-human others whose voices have previously not been heard (see also Jóhannesson, this issue). This can lead to new forms of silencing, as postcolonial critiques argue, in which 'the other' is not able to 'speak' but is always being represented, for instance, by researchers (Spivak, 1988; see also Chambers \& Buzinde, 2016). Instead of giving up on our intentions to know with those who might be more 'difficult' to hear or know-with, it is critical to reflect upon these challenges. We can ask, for instance, what kinds of possibilities and limitations we have when we care for others and wish to re-tell their stories. Linda Tuhiwai Smith (2012, p. 10), the author of Decolonizing Methodologies, argues that researchers should also have answers to questions like 'Whose research is it and whose interest does it serve?' 'Who has designed the questions and framed their scope?' and 'How will the results be disseminated and who will benefit from it?' These questions serve their purpose when we are taking epistemic responsibility (Grimwood, Stinson, \& King, 2019, p. 2) and searching for more holistic approaches to wellbeing in the Anthropocene (see also Lowan-Trudeau, 2018).

The special issue at hand is based on the aforementioned TEFI10 conference, organised on June 3-6, 2018, at Pyhä-Luosto national park in Finnish Lapland. It is a joint issue organised together with the Journal of Teaching in Travel and Tourism (JTTT); the second part will be published in 2020 in JTTT. This issue consists of six research notes and a student's greeting from the conference. The research notes are longer than those usually published in the Finnish Journal of Tourism Research, and all of them have been subjected to an open peer review process by two reviewers. In this way, we wish to create an invitation to reflect, be inspired, and engage with new initiatives of knowing-with. Even though the issue does not address tourism education per se, the theme of knowing-with is also relevant for education - and for the ways we wish to share our knowledge. As Carina Ren and Gunnar Thór Jóhannesson (2018, p. 25) argue, the ideas of making-with and knowing-with help us to challenge tourism as something holistic, coherent, and entirely knowable. In this issue, we understand knowing-with as a relational approach in which knowledge is constantly on the move, escaping essentialism. This means that, instead of aiming 
to fully know, pre-plan, categorise, or organise something or someone, knowing-with becomes possible through embracing plurality, messiness (Veijola, Germann Molz, Pyyhtinen, Höckert, \& Grit, 2014), unfinishedness (Germann Molz, 2014), not-knowing (Grimwood, Stinson, \& King, 2019), unlearning, negotiating (Höckert, 2018), and improvising (Rantala, 2019).

In the first research note, Gunnar Thór Jóhannesson writes that 'tourism is not a singular entity; it is a collaborative achievement, accomplished through heterogeneous relations. It is "becoming with many"' (Haraway, 2008, p. 4). The idea of knowing-with in the Anthropocene challenges the disciplinary boundaries, and, as Jóhannesson suggests, we must be able to disrupt and move beyond the traditional division between social and natural sciences. He argues for 'knowledge practices that rather than seeking to organising the dynamic forces of the Earth once and for all, look for more messy collaborative ways of knowing with nature' (Haraway, 2008, p. 4).

In the second research note, Tarja Salmela and Anu Valtonen reply to the editors' call to re- flect on how we can aim to know-with objects, things, humans, landscapes, animals, elements, and theories through our research activities. They propose walking-with multiple others as a potential way to know-with and elaborate an epistemological reflection on how to carry out knowing-with in the context of tourism research. The paper by Jordana Milne, Outi Rantala, and Bryan Grimwood continues the methodological discussion by focusing on how to conduct research with children - how to know-with children. Similar to the previous research note, it takes us to the forest landscape of northern Finland and focuses on ways of walking-with in nature. The research note important- ly points out how it is not just children who participate in worldmaking during family nature walks. The walks also influence adults' worldviews, which is essential in the era in which we are living; these walks can help adults to slow down and to connect - to know-with.

In his research paper, Mikko Äijälä directs our attention towards non-human others, with the example of sled dogs. Äijälä underlines how animals are not passive participants, but hold power to shape tourism practices and spaces. It is therefore valuable that Äijälä names both theoretical and methodological approaches to be applied in future research endeavours. In a similar vein to Jóhannesson's remark about the need to move beyond disciplinary borders, many of the research notes show how difficult it is to limit discussions merely to tourism contexts. In their research notes, Seija Tuulentie and Jessica Faustini Aquino bring up examples from community development contexts by discussing how environmental knowing can actualise with immigrants and youth in northern communities. The special issue is concluded by Pia-Maria Hokkanen's reflections as a student member of the TEFI1o conference organising team. Her experiences from forest meditations, lunch tables, and poetic spaces tell of the possibilities and challenges of creating multiple connections with our surroundings and about the important glimpses of hope and optimism among us.

At Rovaniemi and Tärnaby, 10 December 2019

Outi Rantala, Emily Höckert, and Heli Ilola 


\section{Acknowledgements}

The editing work of the special issue has been supported by a state subsidy for organising international conferences granted by the Federation for Finnish Learned Societies, by a research project, Envisioning Proximity Tourism with New Materialism, funded by the Academy of Finland (no. 24493), and by Culturally Sensitive Tourism in the Arctic (ARCTISEN) project, funded by the Northern periphery and Arctic (2014-2020).

\section{References}

Alaimo, S., \& Hekman, S. (2008). Material feminism. Bloomington, IN: Indiana University Press.

Barad, K. (2003). Posthumanist performativity: Toward an understanding of how matter comes to matter. Signs, 28, 801-831. https://doi.org/10.1086/345321

Barad, K. (2007). Meeting the universe halfway: Quantum physics and the entanglement of matter and meaning. Durham, NC: Duke University Press.

Bar-On, Y. M., Phillips, R., \& Milo, R. (2018). The biomass distribution on Earth. Proceedings of the National Academy of Sciences, 115, 6506-6511. https://doi.org/10.1073/pnas.1711842115

Braidotti, R. (2013). The posthuman. Cambridge, UK: Polity Press.

Carrington, D. (2018). Humans just $0.01 \%$ of all life but have destroyed $83 \%$ of wild mammals - study. The Guardian, 21 May. Retrieved from https://www.theguardian.com/environment/2018/may/21/human-race-just-001-of-all-life-but-has-destroyed-over-80-of-wild-mammals-study

Caton, K. (2018). Conclusion: In the forest. In B. S. R. Grimwood, K. Caton, \& L. Cooke (Eds.), New moral natures in tourism (pp. 194-205). London, UK: Routledge.

Chambers, D. \& Buzinde, C. (2015). Tourism and decolonisation: Locating research and self. Annals of Tourism Research, 51, 1-16. https://doi.org/10.1016/j.annals.2014.12.002

Germann Molz, J. (2014). Camping in clearing. In S. Veijola, J. Germann Molz, E. Höckert, O. Pyyhtinen, \& A. Grit, Disruptive tourism and its untidy guests: Alternative ontologies for future hospitalities (pp. 19-41). Basingstoke, UK: Palgrave Macmillan.

Gren, M., \& Huijbens, E. (2014). Tourism and the Anthropocene. Scandinavian Journal of Hospitality and Tourism, 14, 6-22. https://doi.org/10.1080/15022250.2014.886100

Grimwood, B. S. R., Stinson, M. J., \& King, L. J. (2019). A decolonizing settler story. Annals of Tourism Research, 79. https://doi.org/10.1016/j.annals.2019.102763

Haraway, D. (2015). Anthropocene, Capitalocene, Plantationocene, Chthulucene: Making kin. Environmental Humanities, 6, 159-165. https://doi.org/10.1215/22011919-3615934

Höckert, E. (2018). Negotiating hospitality: Ethics of tourism development in the Nicaraguan highlands. London, UK: Routledge. https://doi.org/10.4324/9781315147604 
Kugapi, O. \& \& Höckert, E. (2018). Knitting and purling care: Entangled stories of travelling mittens. Paper presented at the 'Re-searching Indigenous Methodologies and Engaging Communities' workshop, 20 November 2018, Inari, Finland.

Lowan-Trudeau, G. (2018). Indigenous methodologies revisited: Métissage, hybridity, and the Thirds Space in environmental studies. In B. S. R. Grimwood, K. Caton, \& L. Cooke (Eds.), New moral natures in tourism (pp. 181-193). London, UK: Routledge.

Puig de la Bellacasa, M. (2012). 'Nothing comes without its world': Thinking with care. The Sociological Review, 60, 197-216.

Puig de la Bellacasa, M. (2017). Matters of care: Speculative ethics in more than human worlds. Minneapolis, MN: University of Minnesota Press.

Rantala, O. (2019). With the rhythm of nature: Reordering everyday life through holiday living. In Halkier, H., James, L. \& Ren, C. (Eds.), Theories of practice in tourism (pp. 58-76). London, UK: Routledge.

Ren, C., \& Jóhannesson, G. T. (2018). Collaborative becoming: Exploring tourism knowledge collectives. In C. Ren, G. T. Jóhannesson, \& R. van der Duim (Eds.), Co-creating tourism research: Towards collaborative ways of knowing (pp. 24-38). London, UK: Routledge.

Ren, C., Jóhannesson, G. T., \& van der Duim, R. Eds. (2018). Co-creating tourism research: Towards collaborative ways of knowing. London, UK: Routledge.

Spivak, G. C. (1988). Can the subaltern speak? In C. Nelson \& L. Grossberg (Eds), Marxism and interpretation of culture (pp. 271-316). Chicago, IL: University of Illinois Press.

Tuhiwai Smith, L. (2012). Decolonizing methodologies: Research and indigenous peoples (2nd edition). London, UK: Zed Books.

Veijola, S., Germann Molz, J., Pyyhtinen, O., Höckert, E., \& Grit, A. (2014). Disruptive tourism and its untidy guests: Alternative ontologies for future hospitalities. Basingstoke, UK: Palgrave Macmillan.

Ulmer, J. B. (2017). Posthumanism as research methodology: Inquiry in the Anthropocene. International Journal of Qualitative Studies in Education, 30, 832-848. https://doi.org/10.1080/09518398 .2017 .1336806 